\title{
5. 間葉系幹細胞を用いた骨の再生医療
}

\author{
山田 陽一 ${ }^{11}$ 上田 実23)
}

\begin{abstract}
要 約 目的：歯周疾患に罹患する患者数は約 4,200 万人，骨粗髹症に罹患している患者数は約 1,000 万人 とされる，歯周病により歯槽骨吸収をきたすと有効な治療法はなく，さらなる吸収を予防するにとどまる． また，骨粗鬆症に対しても実際に治療が行われているのはごく一部である，さらに，歯牙丧失時，義歯等に より修復がなされるが，違和感，痛みに悩まされ，QOL 低下はゆがめない，近年，インプラント（人工歯 根）による咬合再建も可能であるが，骨量不足時などは骨移植が必要となる。 しかし，自家骨採取は侵襲が 大きく，特に，老齢となれば新たな健常部位に侵襲を加えたくないのはなおさらである. 方法：われわれは 幹細胞を用いた再生医療的手法を用いることとした，再生医療の 3 要素の内, 歯周病, 歯槽骨再生の幹細胞 には，腸骨骨䯣より分離した未分化間葉系幹細胞（MSCs）を，足場，生理活性物質には自己多血小板血漿 （PRP）を用いた。この骨再生法は注入型培養骨と呼んでおり，低侵襲組織再生療法である。また，骨粗鬆 症に対しては MSCs を応用することとした．結果：歯周病，インプラントのための歯槽骨再生，腫瘍切除 後の骨移植患者に対する骨延長, 顎裂部骨移植症例に対し, 注入型培養骨を応用し, 良好な結果が得られた.

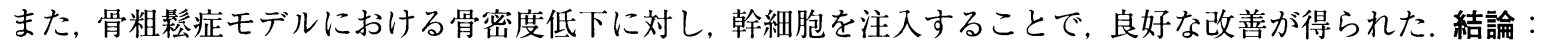
注入型培養骨は，低侵襲で，免疫拒絶を受けにくく，注入型であることにより複雑な形態に対しても応用可 能で, 細胞の再利用も可能などの利点を持ち合わせており, 老齢化社会においても有効であると考えられた. さらに，加齢とともに危険性が上昇する骨粗鬆症に対しても，細胞治療による改善が示唆された．このよう なアンチエイジング医療による細胞治療法は QOL 向上に役立ち，高齢者の幸せな健康寿命を獲得する上で 有効であるとも考えられた.
\end{abstract}

Key words : 再生医療, 注入型培盖骨, 間葉系幹細胞, 骨粗鬆症, 細胞療法

（日老医誌 $2006 ； 43 ： 338-341)$

\section{緒言}

再生医療とは，生体のもつ自然治癒能力を超える組織 の欠損や臟器の損傷に対し, 幹細胞などを用い, 治瘉能 力を人工的に高めることによって，対象とする組織・臓 器を生体自身に再生させることを目的とする医療であ る.この再生医療は幹細胞, 足場（スキャホールド）, 生理活性物質（サイトカイン）という 3 要素の力により 組織再生を行おうとする医療であり，この細胞と足場を

Regenerative medicine for bone using mesenchymal stem cells

1) Yoichi Yamada：名古屋大学医学部附属病院遺伝子 再生医療センター

2) Minoru Ueda : 名古屋大学大学院医学系研究科頭頸 部·感覚器外科学講座 - 顎顔面外科学

3) Minoru Ueda：東京大学医科学研究所幹細胞組織医 工学研究部門歯胚再生学
組み合わせることで自在に生体組織や臓器を再生させる ことができる1”.この点でドナー不足と免疫拒絶という 問題を抱える臟器移植にかわる医療としても注目されて いる，一方，今日の日本では 50 歳以上のエルダー世代 の人達が成人人口の $50 \%$ 以上を占めている，いわゆる 団塊世代以上のひとたちで，このような急速な高齢化が 進む中で, 歯周病䍜患患者数は約 4,200 万人, 骨粗鬆症 罹患患者数は約 1,000 万人とされる．このような加齢と ともに失うことが多くなる歯, 歯槽骨, さらにはごく一 部の患者にしか治療が行われていない骨粗鬆症に対する 治療, 組織再生療法の実現は急務である(四1).

現在, 歯槽骨を造成する場合は, ゴールドスタンダー ドとされる自家骨移植により行われるのが一般的であ る、しかし，自家骨移植では新たな健常部位に侵襲を加 えなければならず，また，採取量にも制限されるという 問題点がある.それに対し，セラミクス (hydroxyapatite, $\beta$-tricalucium phosphate など）や牛由来の Bio-Oss ${ }^{\mathrm{R}}$ など 
高粭化社会にお゙ける肖再生医療

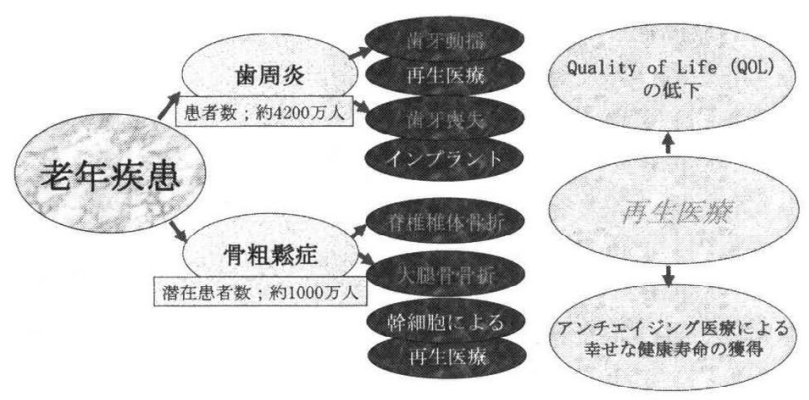

図1われわれの対応している高齢化社会における骨再 生医療

の人工材料が使われることもあるが，本国では認可され ていないものも多く, 安全性, 骨形成能, 吸収期間など 不明確な点が多いとされる，そこで，低侵襲による細胞 を用いた再生医療が注目されるようになってきた。

歯周病に目を向けてみると, 40 歳以上の約 2 割の患 者が重症と言われている。この歯周病は歯周病原性細菌 によって惹起される炎症性疾患であり，進行すると歯を 支える組織が破壊され，歯を衰失する主要な原因の一つ となる。しかし，最近まで歯周病治療はブラッシング指 導, スケーリング, ルートプレーニングなど基本治療を 行い, 炎症性組織や歯石等の異物を除去する原因除去療 法にすぎず，出血をなくすこと，あるいは歯周ポケット を $3 \mathrm{~mm}$ 以下にすることなどを目標の一つにしてきた. 比較的軽い歯周疾患であれば, 歯や歯の周りを清潔に保 つ治療を続けることで治すことができた，しかし，炎症 が歯肉の奥まで進行し，歯周組織の破壊がひどい場合に は, 歯周組織を回復させることは難しいとされる. 今回, 喪失した歯槽骨, 歯周組織の再生を, 幹細胞を用いた組 織再生療法という観点から基礎研究段階から実際の臨床 応用例も含めて紹介する，そして，骨粗鬆症に対する細 胞治療法の可能性についても紹介してみたい.

\section{方 法}

幹細胞として骨䯣由来の未分化間葉系幹細胞 (MSCs) を、また, 細胞の足場, 生理活性物質として, 自己血液 から遠心分離することで精製した多血小板血漿 (Platelet Rich Plasma;PRP) を用い, 再生医学的に骨を再生させ ることを注入型培盖骨 (Tissue-engineered. bone:T.E.B) と名づけだ23. PRPは TGF- $\beta$, IGF, PDGFなどの生 理活性物質の集合体として考えられており，これらサイ トカインのさまざまな㗢きにより, MSCs は活性化され,
骨再生過程が働くと考えたのである.

基礎研究として，抜歯後に犬下顎骨に作製した $10 \mathrm{~mm}$ の欠損を用いて，自家骨，PRP，注入型培養骨を移植す ることによって, 骨再生能, 骨強度, 細胞起源, インプ ラントとの骨結合率, 骨占有率を, 欠損のみの場合を対 照群として比較検討を行った。ささらに，この培養骨の歯 周組織再生能を検討するために, 犬の歯に歯周病感染モ デルを作成した．欠損は移植 2 力月前に, 深さ $5 \mathrm{~mm}$, 幅 $3 \mathrm{~mm}$, 高さ $3 \mathrm{~mm}$ の 2 壁性骨欠損とした，比較検討 した群は 1) negative control としてスケーリング, ルー トプレーニングを注意深く行ったフラップ手術 $(\mathrm{FO})$,

2) positive control として従来の GTR 法を, 実験群と して3）幹細胞と PRPを用いた方法（MSCs/PRP），さ らに 4）GTR 膜と併用した方法（MSCs/PRP/GTR）で 比較した. 組織学, 組織形態学的に上皮の介入率, 新生 セメント質, 新生骨について評価した。この結果に加え て, マイコプラズマ感染の有無, 染色体数, 核型分析, エンドトキシンテスト, 細胞特性についても検討を加え. 臨床応用サンプルにおいても検討を行った．今回 18 例 の臨床応用例のうち，代表的症例を供覧する.

また，骨粗髹症に対する細胞療法として，ラットの卵 巣摘出を行い，骨粗鬆症モデルを作製した．モデルの成 立については体重, さらに骨密度については DXA(dualenergy X-ray absorptiometry) を用いて計測し, 確認 した。幹細胞（MSCs）はラット大腿骨より採取，分離 し，尾静脈より注入した群（general injection）と大腿 骨へ注入した群（local injection）の評価を行った.

\section{成 績}

動物実験において, 歯槽骨再生能について検討を行い, 肉眼的所見としては，コントロール (欠損のみ) や PRP のみを移植した部位では移植後 8 週においても，もと あった骨レベルまで再生が得られていなかったのに対し て, 自家骨, 培養骨では十分な骨再生が得られていた2)-7). SEM 像によるミクロ所見を観察すると，移植初期では コントロール，PRPのみでは結合組織による修復像が 見られたのに対し，培養骨 (MSCs/PRP) では活発な 骨芽細胞，骨細胞が観察された。 また，自家骨では移植 骨の吸収像が観祭された。 そして，再生された骨の物理 的強度をビッカース硬度から検討した結果，移植後初期 から培養骨は優れた骨強度を有していた8”。次に,この 骨形成が移植したMSCsにより行われるかについても 遺伝子工学的に検討した所, 移植した MSCsにより，2, 4, 8 週ごとに骨形成過程にしたがって骨再生が起こっ ていることが明らかとなった.ささらに，インプラントと 
Dental Implant Application Case (Maxillary sinus lift )
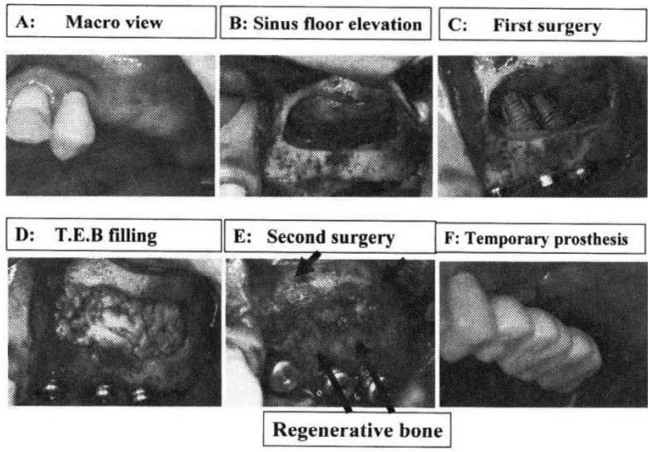

図 2 インプラント (人工歯根)：上顎洞底挙上術による 骨再生の代表的臨床例 $1: \mathrm{A}$ ：術前の口腔内所見. B ; 上顎洞底を挙上した所. C ; インプラントを埋入した 所. インプラント周囲には骨がなく，スレッドの露出 が見られた. D ; 注入型培養骨 (T.E.B) をスレッド露 出インプラントの周囲に応用した. $\mathrm{E} ; 6$ 力月後, 培養 骨により再生された骨. F; 暫間菌冠補緅終了後, 良好 な咬合再建が達成されている。

の関係についても検討し，コントロール，PRPがイン プラント植立に対し，十分な骨再生が得られていなかっ たのに対し，培養骨による骨形成はインプラント植立す るに十分な骨量が再生されていだ)。 しかし，PCBMで は移植骨による吸収像が観察された、インプラントとの 結合率についても自家骨に優り，母骨に近い骨結合率が 達成されていた.

幹細胞と PRP を用いた培養骨による歯周組織再生療 法は GTR 法と比較しても上皮の介入も防ぐことできて おり, 新生骨量には大きな違いは見られなかったものの, 新生セメント質の再生能力は優れ，FO， GTR 法と比較 しても高値を示した，さらに詳細に検討した結果，以前 から知られているように GTR 法で再生されたセメント 質は有細胞セメント質であったのに対し，幹細胞と PRP により再生されたセメント質は天然のセメント質と同じ 有細胞セメント質と無細胞セメント質により再生されて いたことは驚くべきことである。したがって，この再生 された歯周組織は本当の意味での蒾周組織再生が行われ たと考えている.

臨床応用例について代表的症例を供覧する，まず，臨 床のプロトコールの概略として，腸骨骨稜より局所麻酔 下にて骨髄液を採取する。1 1 力月から 1.5 力月程培養操 作を行い，必要となる細胞数まで細胞を増殖させる．そ して，培養骨移植術前日に，末梢血より PRP を輸血部
Cell therapy for osteoporosis ( $\mu$ CT evaluation )
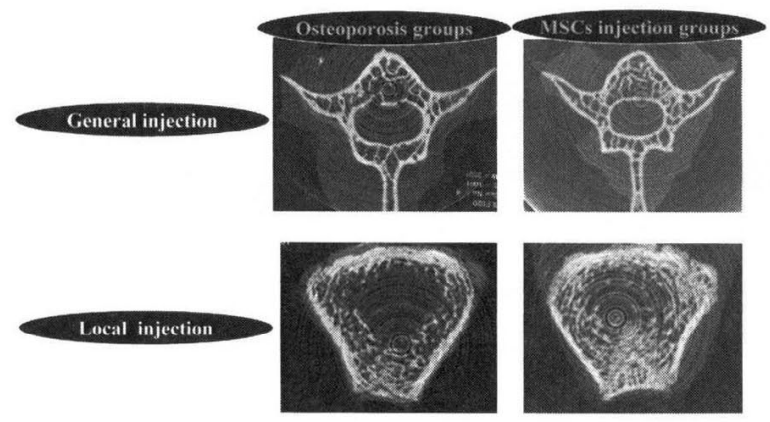

図３骨粗鬆症に対する細胞治療法によるアプローチ ( $\mu$ CT による評価)

骨粗鬆症モデルに対する全身投与 (general injection) と 局所（大腿骨投与）（local injection）により，骨梁の改 善が見られる.

にて無菌的に採取する．手術時にMSCs と PRPを混合 することにより適応部位に応用するのである ${ }^{618)}$. 症例 $1:$ 上顎左 $5 \sim 7$ 欠損症例で，咀嚼障害を主訴に来院され た 56 歳女性である。インプラント埋入予定部位には十 分な骨量がなく，骨造成なしにはインプラントによる咬 合再建が難しいと考えられた。 そこで，上顎洞底挙上術 を行い, インプラント 3 本埋入し，骨量不足部位に注入 型培養骨移植術を適応した. 6 力月後の 2 次手術時には 十分な骨再生が得られており，現在，暫間補緅物により 経過観察中であるが, 経過良好である（図2）.

骨粗笮症に対する細胞療法として，卵巣摘出後，DXA による骨密度の低下が観察された。この骨粗鬆症モデル の成立後，MSCs を全身投与した所，脊椎に打ける骨密 度に改善が見られ，また，大腿骨に局所投与した場合に も改善が見られた， $\mu \mathrm{CT}$ による結果からも，DXAの結 果が裏づけられた（図3）。

\section{考察}

今後，ますます高齢化社会が進む中で，老人医療費や 高度先進医療費の高騰は国家レベルでの問題となってく るであろう，特に，臓器不全に対する治療は移植医療や 人工藏器治療など医療費負担が大きい，患者の生活能力 の回復を可能とするだけでも，医療費の大幅削減と社会 への還元が見込まれる．本方法では，自己の幹細胞，血 小板を用いているために，ドナー不足，免疫拒絶という 問題は回避できる．また，トロンビンを加えることでゲ ル化させることができた．このように，注入型とするこ とで操作性，賦形性の面にも優れており，適応は閉鎖胿 
を有する空洞状骨欠損に刘し, 最適であると考えている. 症例としてはインプラントのための蒾槽骨再生, 歯周病, 囊胞, 顎裂部骨欠損などが考えられる. 現在, 自家骨や 人工骨を用いて骨再生を行わないとインプラント植立が 不可能であった症例や審美性が要求される症例に対して も，幹細胞を用いることで低侵襲の骨増生が可能となり つつある。このような欠損は顎顔面領域に限らず無数と いってよいほど存在し，適応症は多いと考えられる，さ らに, 年間 15 万人に骨折が生じ, 現状では固定療法し かないとされる骨粗鬆症罪患患者に対する注入療法の応 用の可能性も示唆された，幹細胞を注入することで骨稜 の強化, 骨再生も期待されるのである. このような患者 さんにとって負担の少ない治療法の開発は再生医療の長 所がもたらす福音といえるであろう.

再生医療は工学と生命科学の共同した学際科学により 発展してきた学問であり，三要素の一つである生きた幹 細胞の利用が鍵ともなる. 現在, このように幹細胞を用 いたティッシュエンジニアリング技術が治療に用いられ る時代が到来し，トランスレーショナルリサーチの段階 を経て，いよいよ実用化の段階に入ったと言えるであろ う. 今後, 安全性確保のために細心の注意を払う必要も ある、ただし，形式的指針や各種取り決めに従っていれ ばよいというわけではなく, 研究にかかわるものが責任 の重さを自覚し，最良と考えられる方法を常に考え，良 心にのっとり行うことが重要である. 時には自発的な取 り決めを設けることや必要とあれば新たなシステム導入 に積極的であるべきである，そして，臨床経過の中で改 善すべき点は改良を行い，よりよい医療として普及させ ていくことが必要であると考えている，再生医療として 実現・定着そして普及させるためには, 基礎研究機関と 医療機関の連携だけではなく，産業化という形で商品化 や販売を行う企業との連携も重要である. 今回，この注 入型培養骨の歯科領域への応用はアルブラスト社という ベンチャー企業を通じて, 当科から技術移転, 産業化が 進められている. 今後, 産業化に向けて, 効率的産学連 携が望まれる。科学性, 安全性, 倫理性が十分配慮され ることにより, 医療制度, 薬事法, 医事法, 保険制度な どをクリアーし，一日も早く再生医療が患者さんに帰依
することを望んでやまないとともに，健康寿命を長くと いう社会のニーズに応えるべく, 出来る限り貢献してい きたいと考える.

\section{文献}

1) Langer R, Vacanti JP : Tissue engineering. Science 1993 ; $260: 920-926$.

2) Yamada Y, Boo JS, Ozawa R, Nagasaka T, Okazaki Y, Hata $\mathrm{K}$, et al.: Bone regeneration following injection of mesenchymal stem cells and fibrin glue with a biodegradable scaffold. J Cranio-maxiillofac Surg 2003 ; 31 : 2733.

3) Yamada Y, Ueda M, Naiki T, Takahashi M, Hata K, Nagasaka $\mathrm{T}$ : Autogenous injectable Bone for Regeneration with Mesenchymal Stem Cells (MSCs) and Platelet-Rich Plasma (PRP)-Tissue-engineered bone regeneration-. Tissue Eng $2004 ; 10$ : 955-964.

4) Yamada $Y$, Ueda $M$, Naiki $T$, Nagasaka $T$ : Tissueengineered injectable bone regeneration for osseointegrated dental implants. Clin Oral Impl Res 2004 ; 15 : 589597.

5) Yamada $Y$, Ueda M, Hibi H, Nagasaka T : Translational research for injectable tissue-engineered bone regeneration using mesenchymal stem cells and platelet-rich plasma-from basic research to clinical case study. Cell transplant $2004 ; 13: 343-355$.

6) Ueda M, Yamada Y, Ozawa R, Okazaki Y : A clinical report of injectable tissue-engineeed bone applied for alveolar augmentation with simultaneous implant placement. Int J Periodontics Resrtative Dent $2005 ; 25$ : 129137.

7) Ito K, Yamada Y, Nagasaka T, Baba S, Ueda M: Osteogenic potential of injectable tissue-engineered bone:a comparison among autogenous bone, bone substitute $\left(\right.$ Bio-Oss ${ }^{\mathbb{B}}$ ), platelet-rich plasma (PRP), and tissue-engineered bone with respect to their mechanical properties and histological findings. J Biomed Mater Res A $2005 ; 73: 63-72$.

8) Yamada Y, Ueda M, Hibi H, Baba S, et al. : A novel approach to periodontal tissue regeneration with mesenchymal stem cells (MSCs) and platelet-rich plasma (PRP) using tissue engineering technology - a clinical case report- Int J Periodontics Resrtative Dent, in press. 